\title{
Approaches to the Development of a Child's Personality According to Carl R. Rogers
}

\section{Eva Šmelová}

\begin{abstract}
The aim of the paper is to introduce some of the thoughts of an American psychologist Carl R. Rogers, known especially for his non-directive approach in psychotherapy. Rogers' thoughts influenced not only treatment but also the area of pedagogy, where he promotes natural and peaceful education, authenticity and self-fulfilment. In his work, he addressed the issues relating to the development of freedom of learning through various approaches and strategies.

The contemporary preschool education is undergoing a transformation process, whose objective is to establish approaches to a child as an active subject, who is developed with respect to own potentialities, needs and interests, in a supportive environment with an atmosphere of freedom.

The paper deals with educator approaches verified by research as the most effective methods of learning facilitation, and with strategies according to Rogers. The paper describes approaches that can be well implemented into the work of preschool educators and can enrich the repertoire of their facilitation approaches, which encourage appropriate children's activities, learning, thinking, self-understanding and understanding the surrounding environment.
\end{abstract}

Keywords: kindergarten teacher, preschool education, learning, preschool child, nondirective approach, freedom, experiential learning, congruence, empathy, acceptance. 


\section{Introduction}

Before 1990, preschool education in the Czech Republic primarily focused on children education through a predetermined content. Such content was presented by the teacher primarily by means of collective work, i. e. in a frontal manner. In these types of controlled joint activities, children were left with a minimum space for freedom. The teacher had to follow not only the content but also the programme of activities. Obviously, these conditions did not respect individual children's needs. After 1989 this approach was strongly criticized by teachers themselves, as it was unsuitable not only for the child but also for own creative educational work.

Since 1990 there have been efforts to develop a new approach to children associated with pedagogical thinking and turning to the legacy of the humanistic school of psychology, where the child's freedom is in the forefront. These schools become the source of personalistic theories. Their development was influenced by the work of educators at the beginning of 20th century. One of them was M. Montessori, who devised an approach to child-centred education, as expressed by her known credo: "Help me do it."

The personalistic theories were also inspired by personalistic psychology, which reacted to deterministic psychology trends based on a concept that a human is controlled by the unconscious or his living environment. The effort was to bridge the gap between two psychology theories with the power of the unconscious on the one hand and the influence of the surrounding environment on the other. The aim was to highlight the interaction personality concept which was later identified as personalistic psychology. A significant figure was A. Maslow, who together with other researchers developed a new picture of a human being with innate love and own fulfilment contributing to the good of the whole society. Another source of personalistic theories is the work by K. Lewin, father of the dynamic theory of personality. Under the above mentioned thoughts the following two movements originated:

- pedagogical approaches focusing on the development of affectiveness through non-directive strategies,

- pedagogical approaches focusing on the development of creativity through direct intervention strategies, (Bertrand, 1998, p. 44-47).

Rogers is a representative of non-directive strategies. He is the founder of psychotherapy, which is based on a non-directive (non-manipulative) and relationship-based approach to helping people through psychological instruments. (Vymětal in Baštecká 2009, p. 324) The Rogers' approach is used not only in treatment but also the area of humanistic pedagogy, where he promotes natural and peaceful education, authenticity and self-fulfilment. The teacher-student relationship changes; it becomes less directive and is based on mutual respect and understanding. (Průcha et al. 2009, p. 93) To a large extent, the mentioned approaches correspond with the current requirements of the 
preschool curriculum. The question is however, to what extent and which approaches recommended by Rogers can be appropriately used in preschool education.

\section{Human centred approach}

Speaking of the relationship between the educated and the educator, these two are usually assigned different roles: the subject and object of education. In today's educational concept, this relationship is rather an external phenomenal matter because during the course of this interaction the roles are exchanged. The object of education is also the subject, irrespective of the individual's level of maturity. Incorrect understanding of this relationship results in the dominance of the adult individual as the subject of education; this individual becomes a manipulator, does not allow communication or free expression of the object, i.e. the educated. The consequence of this unhealthy relationship is insufficient development of potential pedagogical, individual and social subjectivity. External efforts of educators should encourage and direct the internal conscious self-formation of the educated and lead them to a transition to self-educators and educators of others. (Bližkovský 1992, p. 34-35)

The human-centred approach is not mere learning certain behavioural techniques; it also encompasses the area of approaches and interpersonal relationships. "The human-centred approach is primarily a way of being, which is reflected in the attitudes and ways of conduct comprising a growth-promoting climate. This is rather a philosophy than a technique or method. Living by this philosophy helps humans develop their own capacities. If this philosophy is lived out, it also stimulates constructive transitions in others. It gives humans strength and our experience shows that if this strength is felt, the development is directed towards personal and social changes." (Nykl 2012, p. 31)

The core of this approach is based on the following attitudes: acceptance, empathy and congruence, which is the basis of Rogers' non-directiveness. His approach cannot be limited just to the mentioned variables. The Rogers' theory encompasses a number of other aspects: extensive theory of personality and behaviour, definition of multiple concepts, self-theory (structure and differentiation of mental processes), definition of the causes of mental disorders, detachment from clinical diagnosis, application of this approach in education, etc. The theory is based on an own humanistic concept of the image of man, which was in contradiction to psychoanalysis and behaviourism. Rogers believed that every man has a rich intrinsic mental potential, which is released and developed under suitable conditions towards self-understanding, understanding and acceptance of own environment and constructive changes in relationships and conduct. Each individual has a need not only to take but also to give, perceive others in the surrounding environment and be perceived, develop, be able to assess oneself. 
For example, the relationship between the mother and her child is characterized by strong emotions, closeness, understanding, empathy, communication, etc. Being able to empathise is directly associated with self-knowledge, the level of which depends on personal maturity and internal stability. The level of empathy reflects willingness to empathise, ability to accept another person and being verbally skilful. An emphatic adult promotes children's feelings of subjective closeness and trust. A sincere interest of an adult in a child, understanding and closeness develop a feeling of safety, integrate and promote the development of the child's self-respect. For a child, an adult is a model of understanding behaviour, which promotes and increases the child's self-empathy. An adult's empathy has a positive effect in terms of relationships, emotions and cognition. It leads to changes in self-conception, and in overcoming incongruences (internal conflicts). The foundations of developed forms of empathy are laid in childhood.

Empathy is developed especially in social interaction and in the relationship between a child and an adult from birth, all this on the basis of congenital predispositions of various levels. The first stage of the development of empathy is "pre-empathy", which is characterized by an involved emotional reaction, sensational communion, emotional contagion and assumption of feeling; for example a reaction of a child to another child crying. Another type of assumption of feeling can occur when a differentiated emotional reaction or a permanent condition of a close person from a child's environment induces identical feelings in the child. A significant aspect in the development and cultivation of empathy is quality interaction, in which subjectivity emerges from inter-subjectivity. As it turns out, highly emphatic individuals are internally stable and have a higher level of self-knowledge, positive and helpful relationship with other people. A quality and inspiring interaction between a child and the teacher requires winning the child's trust, which is associated with being authentic. Authenticity is a significant personality feature reflected in sincere behaviour, being oneself, act without pretending. It is important to be authentic not only with respect to other people but also with respect to oneself. (Nykl, 2012, p. 90-92)

Congruence is another significant attitude in developing a relationship of mental growth. It represents an agreement between internal experiencing and external behaviour. This agreement is significant for healthy mental development, ability to communicate and healthy interpersonal relationships. Sometimes this balance is disrupted, which might be associated with prejudice or conventions. In that case, what adults say and do differs from what they think, which may lead children to non-authentic conduct. Children come to kindergarten with certain habits and behaviour, which may not be in line with the requirements for proper behaviour in kindergarten. Under the influence of these situations, children behave non-authentically and are led to pretence by their parents. For the child such behaviour presents a degree of load. Gradually, behavioural norms and rules are adopted that the child cannot identify with and it is difficult for 
the child to comprehend such situation. Non-authentic behaviour can be induced not only by the family but also kindergarten.

Congruence in the Rogers' concept involves experiencing and awareness free from strict constructs, internal undistorted symbolization of experiencing, social and transparent expression towards another person, the fact that an individual is capable of living a fulfilling sense in a relationship. (Čáp, Mareš 2007, p. 355)

A need in interpersonal relationships is true sincerity and an ability to live out actual feelings and attitudes. If a child feels ununderstood, openness cannot be expected. For example, children also assume the teacher's attitude to another child. Children do not want to play with a reprimanded child and express rejection. A rejected child becomes withdrawn or can behave aggressively and deliberately draws attention by inappropriate behaviour. It might be concluded that it is impossible to build relationships without empathy and congruence.

As Rogers aptly says: "I find I am limited in some situations, I do something badly or I ridicule myself. I can highlight these traits if they occur during an interaction. If a therapist is himself and expresses openly, he frees us from numerous restraints and affectations and allows a client to establish a contact with another human being in the most pleasant way." (Nykl 2012, p. 38)

The basic attitudes of the teacher-facilitator as considered by Rogers include trust in man, experiencing uncertainty of discovering, research-based evidence, student-based evidence and effect on the teacher.

Should we work with children we should believe in developing their potentialities and provide them with a space for a free educational selection, through which children are educated. The educator should develop the child through his/her interests, respecting individual possibilities and needs. Educators are often convinced that they need to guide the children at all times according to what they think is best. As a result, children are often manipulated irrespective of their individual interests and needs.

The teacher can show trust in the child by providing the "freedom to learn", i. e. respect for individual peculiarities. And by creating conditions for experimenting, discovering, cognition, which makes learning an everyday enjoyable part of the child's life.

As Rogers aptly says: "If we want to have citizens who are able to live in this kaleidoscopically changing world in a constructivist way, we need to free our children so that they can start to learn independently. This type of a learning individual can well develop into a facilitator promoting human growth." (Rogers 1998, p. 178-195)

For a child's development it is necessary to provide a stimulating environment, which is the task of kindergarten teachers. A significant aspect according to Rogers is centred care of the teacher for his/her own class, which strengthens facilitating conditions required for encouraging children's activities in a cooperative learning environment. (Rogers 1998, p. 268) 
The following table compares some forms of behaviour in a teacher centred class or human-facilitator centred class according to Rogers. The last part of the table includes the application of a human-facilitator centred environment in kindergarten.

\section{Table 1}

Comparison of discipline in a teacher centred class and human-facilitator centred class

\begin{tabular}{|l|l|l|}
\hline \multicolumn{3}{|l|}{ Comparison of discipline in a teacher centred class and human-facilitator centred class } \\
\hline Teacher centred class & Human centred class & $\begin{array}{l}\text { Application in kindergartens } \\
\text { (the level can be reached as early as } \\
\text { in older preschool children) }\end{array}$ \\
\hline The teacher is the only leader & Joint leading & Joint leading \\
\hline Leading in the form of supervision & Leading in the form of guiding & $\begin{array}{l}\text { Leading in the form of guiding } \\
\text { The teacher creates necessary conditions. } \\
\text { Children address various tasks, } \\
\text { select activities that are of interest. } \\
\text { Emphasis on the child's experience. }\end{array}$ \\
\hline The teacher sets the rules & $\begin{array}{l}\text { The teacher sets the rules together with } \\
\text { the children. }\end{array}$ & $\begin{array}{l}\text { The teacher sets the rules together with } \\
\text { the children. } \\
\text { The rules are not only set and observed } \\
\text { jointly by the children but also assessed } \\
\text { in the context of self-reflection of own } \\
\text { conduct and conduct of others. }\end{array}$ \\
\hline Rewards are mostly extrinsic & Rewards are mostly intrinsic & $\begin{array}{l}\text { Rewards are mostly intrinsic. The } \\
\text { teacher uses especially praise and other } \\
\text { methods, e. g. task assignment, etc. }\end{array}$ \\
\hline $\begin{array}{l}\text { The teacher has only a few helpers } \\
\text { among the pupils }\end{array}$ & $\begin{array}{l}\text { All pupils have an opportunity to } \\
\text { become an integral part of taking care } \\
\text { of the class. }\end{array}$ & $\begin{array}{l}\text { All children have an opportunity to } \\
\text { become an integral part of taking care } \\
\text { of the class. }\end{array}$ \\
\hline
\end{tabular}

\section{Experiential learning according to Carl R. Rogers}

Preschool education uses spontaneous as well as controlled activities that are interconnected and balanced, whose proportion corresponds with the needs and possibilities of a preschool child. A specific form suitable for preschool education is a didactically oriented activity directly or indirectly motivated by the educator, which includes both spontaneous and deliberate (targeted, planned) learning. (RVP PV 2004)

Natural features of a preschool child are curiosity, endeavour to explore, discover, and experiment, all of which lead to learning. Then it depends on the conditions and the educator whether the learning process is supported or limited. 
Rogers distinguishes two types of learning:

- learning that engages the mind, without feelings, personal significance, with no associations with the whole person,

- experiential learning.

In preschool age experiential learning has a significant position because it is easier for children to remember what is directly associated with a specific object or activity, i. e. experience. Storing any knowledge in the memory is also influenced by the degree of awareness of a specific area.

According to Rogers experiential learning is characterized by the following: quality of personal experience, own initiative, penetrance, assessment of experience and its significance for the learner. (Rogers 1998, p. 215)

The quality of personal experience is associated with emotional as well as cognitive aspects of a child's personality. For a preschool child a majority of experience is associated with an actual situation related to satisfaction or dissatisfaction. A significant role in controlled activities is played by extrinsic motivation, which then transforms into internal feelings.

The quality of learning is associated with the meaningfulness of a specific piece of knowledge, relationship to the child's life and the child's experiences. Processing of any new knowledge in the memory is influenced by the degree of the child's awareness of a specific area, which is a precondition for easier remembering.

In preschool children, the process of assessment is associated with emotional experiencing. A majority of experience at this age is associated with a specific situation related to satisfaction or dissatisfaction. (Vágnerová 2012, p. 219-221)

Assessment should not be performed solely by the teacher but space should be provided for the child's assessment and self-assessment, who is thus led to co-responsibility. Rogers emphasises the fact that education that provides space for the subject of learning brings deeper understanding and remembering. At the same time, the child's self-confidence is supported. According to Rogers, self-assessment is of primary importance; assessment of another person is of secondary importance. (Rogers 1998)

In recent years, a specialized type of active learning is used especially in science classes, i.e. discovering. The school curriculum of a number of contemporary kindergartens includes projects aimed at discovering, i. e. exploration. Teachers intentionally present elementary problems that children solve. These can be short-term as well as long-term projects. Teachers take the role of facilitators, whose primary task is to initiate appropriate activities, provide a suitable environment and offer children opportunities to find out, think, understand oneself and the environment. They become guides on the way to children's cognition. As mentioned by Rogers, a human-facilitator centred class shapes not only the children but also the teachers. 


\section{Conclusion}

The reform of preschool education launched in the previous decade has not been completed yet. New requirements and legal amendments present mere regulations that introduced a number of changes into the work of schools, these changes often being non-conceptual. The new curriculum designed in compliance with current educational trends is not a guarantee of quality education. This can only be guaranteed by a qualified professional approach of the teachers to designing own work, and by acquiring new educational strategies based on the child and the child's needs. The transformation of kindergartens should be based on this principle. As indicated above, Rogers' personalistic approaches and strategies might be implemented in the work of kindergartens with respect to the specifics of preschool age and well connected with current knowledge presented by the followers of cognitive psychological (Piaget) and sociocognitive (Vygotský, Bruner) theories.

\section{References}

Baštecká, B. ed. (2009). Psychologická encyklopedie - Aplikovaná psychologie. Praha: Portál.

Bertrand, Y. (1998). Soudobé teorie vzdělávání. Praha: Portál.

Bližkovský, B. (1992). Systémová pedagogika. Ostrava: AMOSIUM.

Čáp, J., Mareš, J. (2007). Psychologie pro učitele. Praha: Portál.

Nykl, L. (2012). Carl Ransom Rogers a jeho teorie - Př́stup zaměřený na člověka. Praha: Grada.

Rámcový vzdělávací program pro předškolní vzdělávání. (2014). Praha: VúP.

Rogers, C. R. \& Freiberg, H. J. (1998). Sloboda učit'sa. Modra: Persona.

Šmelová, E. (2014). Bezvýhradná akceptace ve výchově dítěte. Olomouc: Pedagogická fakulta UP.

Vágnerová, M. (2012). Dětství a dospívání. Praha: Karolinum.

\section{Contact:}

doc. PhDr. Eva Šmelová, Ph.D.

Palacký University, Olomouc

Faculty of Education

Žižkovo nám. 5

77140 Olomouc

E-mail: eva.smelova@upol.cz 